\title{
"Evolution of post-crisis bank regulations and controlling tools: a systematic review from a historical aspect"
}

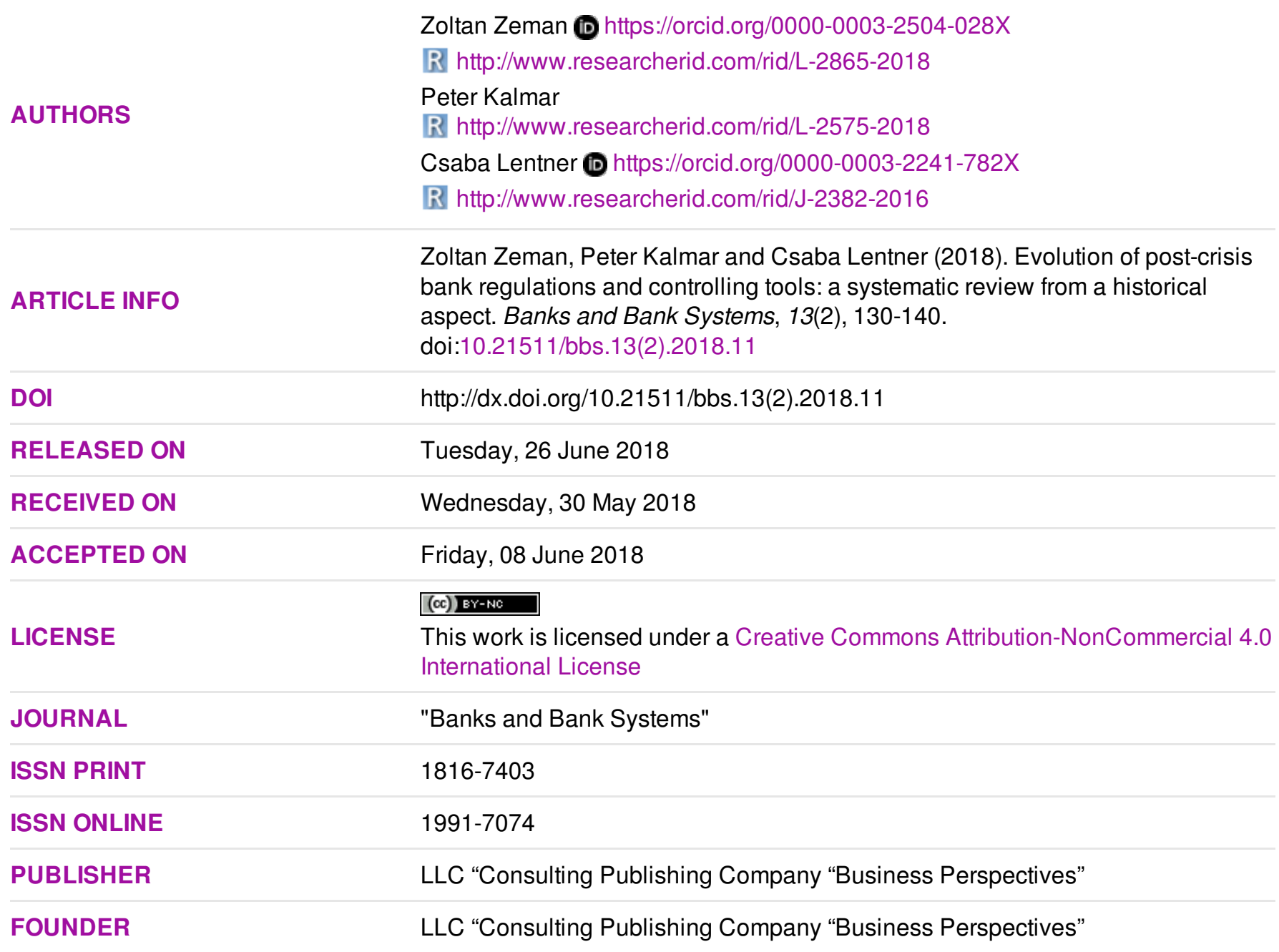

NUMBER OF REFERENCES

27
NUMBER OF FIGURES

3
NUMBER OF TABLES

1

(C) The author(s) 2022. This publication is an open access article. 


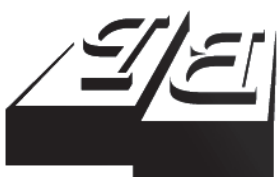

BUSINESS PERSPECTIVES

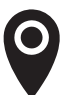

LLC "CPC "Business Perspectives" Hryhorii Skovoroda lane, 10, Sumy, 40022, Ukraine

www.businessperspectives.org

Received on: $30^{\text {th }}$ of May, 2018 Accepted on: $8^{\text {th }}$ of June, 2018

(C) Zoltan Zeman, Peter Kalmar, Csaba Lentner, 2018

Zoltan Zeman, Full Professor, Dr., Head of Department of Szent István University, Hungary.

Peter Kalmar, Ph.D., Dr., Deputy Head of Business and Retail Distribution Analytics at Santander UK Plc, United Kingdom.

Csaba Lentner, Full Professor, Dr. Head of Department at National University of Public Service, Hungary.

\section{(ㄷ)(1) $(8)$}

This is an Open Access article, distributed under the terms of the Creative Commons Attribution-NonCommercial 4.0 International license, which permits re-use, distribution, and reproduction, provided the materials aren't used for commercial purposes and the original work is properly cited.
EVOLUTION OF POST-CRISIS BANK REGULATIONS AND CONTROLLING TOOLS: A SYSTEMATIC REVIEW FROM A HISTORICAL ASPECT

\begin{abstract}
Amongst other causes, the excessive and uncontrolled credit growth, the high levels of leverage with insufficient high-quality capital funding, the high degree of systemic risk accompanied with the inadequate capital buffers and the insufficient liquidity buffers and excessive exposure to liquidity risk (Coen, 2016) in the early 2000's led to first global financial crisis of the millennium in 2008-2009. Although there has been a global effort to consolidate the financial markets, different countries had different levels of regulatory response to the financial crisis, which resulted in different speed of recovery and impact on internal management control processes.

This paper delivers a comprehensive review of the key global changes in the financial market and banking regulations since the 2007-2008 financial crisis by conducting a systematic review of the published papers, directives and regulations of the global, especially the new and existing American, European and Ukrainian financial regulatory bodies and International Organizations such as the Basel Committee, IMF, FSB, EU Parliament and Commission. Trend analysis provides some evidence for the stabilization effect of the new regulations, especially in case of countries with stricter supervisory frameworks (such as the Basel Standards). Finally, the impact of the regulatory environment's changes on the existing internal controlling systems and functions of financial institutions is assessed by comparing the key pre- and post-crisis states of the different management control functions.
\end{abstract}

Keywords

JEL Classification banking, management control, financial crisis, regulation

G21, E50, M48

\section{INTRODUCTION}

The foundation of a successful bank operation is the responsible and prudent management that incorporates the national and international regulations; complies with the direct and indirect governmental and international supervisory expectations; and actively collaborates with the auditory bodies. Since the recent financial crisis, disciplines related to bank management have put an emphasis on the regulatory systems, especially on the direct and indirect tools and processes of central banks; and international regulatory organizations. The strong competition (Hanggraeni, 2018) in the fast-paced banking sector not only challenges the financial institutions themselves but also the national governments. On the one hand, they are responsible for the constant monitoring and management of market imperfections through the correction of information asymmetry, regulation of competition and the periodic audits. On the other hand, governments should also provide the political and economic stability as well as the growth, which is required for sustainable business development for banks and other market participants. If we think about the financial aspect of the national policies, the impact is likely to go across borders which requires governments to coordinate 
not just regionally but also globally (BIS, 2010). As a result, several fiscal and government tasks are now delegated to international levels. The cross border governmental collaboration can prevent gaps between the financial and other sectors, which had ultimately contributed to the last financial crisis. This post crisis inter-sectoral activity eventually led to the formation of a set of new administrative functions around the crisis management of financial institutions and the entire banking sector (Kapoor, 2010). Since the financial crunch, the shift in focus towards financial markets and institutions is visible across the European Union and in fact across the globe. Due to the globalized nature of financial processes or even the national economy, the stable and efficient operation of banks and their transmission mechanisms are nowadays considered as world economic interest. This is a completely different approach to bank regulations compared to the regulatory environment in the decade leading up to the 2008-2009 financial crisis. In the neoliberal market economy, the dominating approach to bank supervision pre-crisis was the 'free banking' philosophy, which accepts minimal or none governmental regulations of the financial services market (Rothbard, 2008). According to the free banking theory, there is no need for the government to regulate and audit banks because as autonomous members of the market these organizations have vested interest in their own profitable and prudent operation which by default should satisfy the basic requirements of the regulator too. Even central banks have primarily focused on the monetary aggregates and the inflation targets instead of the financial system stability (Hartwell, 2012). During this time, the internal management controlling systems at banks primarily focused on planning, budgeting and the financial measurement system with little influence on administrative controls and compensations. Following the crisis, management control professionals, including management accountants, risk managers, compliance managers and even internal auditors played a vital role in the restructuring of management controls, restoring customer and investor confidence and establishing a new external transparency where certain controls were made transparent, observable and in some cases even governable by regulatory bodies (CIMA, 2016). The Management Control functions at financial institutions on top of the original tasks nowadays incorporate cultural controls, risk and compliance, performance and reward controls as well as the oversight of administrative controls through a variety of controlling tools and techniques.

\section{LITERATURE REVIEW OF KEY LEGISLATIONS AND ASSESSMENTS}

Following the 2008-2009 financial crunch, the focus of developed countries (especially in Europe and the USA) was on the reform of market regulations and supervisory bodies. Some countries, for example Hungary and Ukraine, had to also tackle other aspects of the banking crisis. Due to economic shock, the national currencies of these countries have dropped significantly against other currencies (in 2008, the Ukrainian hryvnia dropped 38\% against the US dollar, and the Hungarian forint dropped 28\% against the Swiss franc). Since many loans and mortgages were issued in dollars but most Ukrainians paid in hryvnias, the volume of outstanding capital debt had significantly increased for businesses and the public (in Hungary similar foreign loan products existed at the same time but most of the loans and mortgages were issued in Swiss franc and paid in forints).
One of the first global conferences following the crisis to focus on the consolidation of the financial markets was the Pittsburgh G20 meeting in September 2009. Shortly after, in line with the outcomes of the G20 meeting, the European Parliament has also issued a cross sectoral analysis detailing the identified causes of the crisis and reform solutions. The following observations were highlighted: the serious limitations in the regulatory and supervisory system; the uncontrolled risk appetite of some financial institutions; and the 'soft' monetary policies of some countries (Financial Stability Oversight Council, 2011). Based on the analysis, the following areas of regulatory focus were identified: "building high-quality capital and mitigating pro-cyclicality; reforming compensation practices to support financial stability; improving over-the-counter derivatives markets; addressing cross-border resolutions and systemically important financial institutions; and reforming supervision in the financial sector, consistent with the global framework" (European Parilament, 2010). In the same year, the European Union (with 
the USA and other countries) committed to transform the system of global financial regulations, especially around the topics of financial institutions with stricter rules on risk-taking, governance that aligns compensation with long-term performance, and overall greater transparency which also meant improved tax transparency and the exchange of information so that countries can fully enforce their tax law to protect their tax base. One of the most important characteristics of these commitments was the centralized cross-border cooperation approach on crisis management. This enables regulatory bodies to identify and monitor financial institutions with systematic risks for example.

Following the commitments made by the European Union, the first set of actions were published in the European Market Infrastructure Regulation on derivatives, central counterparties and trade repositories (EMIR) legislation in 2010 (and were finally implemented in March 2013 with further amendments to be implemented in 2018). As the financial crisis has brought the over-the-counter (OTC) derivatives market to the forefront of regulatory attention (with the near-collapse of Bear Sterns in March 2008, and the default of Lehman Brothers in September 2008 or the bail-out of AIG), the EMIR aimed to tackle the issue around some of the most transparent and high-risk products (particularly the credit default swap (CDS) transactions on a central counterparty (CCP)) and limitations in the processes of this market. Following the first assessment, the European Commission set out the first short-, mid-term approaches for the legislative frameworks, i. e. to look at increasing transparency and reducing counterparty credit risk and operational risk through the use of post-trading market infrastructure (European Commission, 2010). European regulators for the next eight years continued to focus on long-term strength and resilience of the banking sector by working closely the Basel Committee on Banking Supervision (BCBS) on the implementation of the Basel III accord (discussed later in the article in details).

In parallel with the European regulatory efforts, in the U.S., the Dodd-Frank Wall Street Reform and Consumer Protection Act was introduced in 2010. As the opening statement of the act says, "this collection of regulations was commissioned to promote the financial stability of the United States by improving accountability and transparency in the financial system, to end "too big to fail", to protect the American taxpayer by ending bailouts, to protect consumers from abusive financial services practices, and for other purposes" (Dodd \& Frank, 2010). In the past eight years several amendments and related regulations have been published to harmonize global efforts.

From an academic research perspective several authors have been analyzing the change in the legislative environment. One of the most published authors in this field is Moosa, who has been researching different aspects of the neoclassical finances and the financial behavior (Moosa, Ramiah, \& Xu, 2015). Handorf has been studying extensively the "financial implications of transitioning to the Wall Street Reform and Consumer Protection Act of 2010 and Basel III" (Handorf, 2017) or Rhodes who has been publishing scientific articles around the EU and US responses to the financial crisis. In general, major journals such as the Banking and Finance Review, Banks and Bank Systems, International Journal of Banking, Accounting and Finance or the Journal of Banking Regulation published many articles detailing analyses and researches about the post-crisis regulations since 2008 .

\section{OBJECTIVES AND METHODS}

The current study has three key objectives.

1. The first objective is to provide a comprehensive review of the global changes in the banking regulations since the 2007-2008 financial crisis. This is completed through a systematic review of the published papers, directives and regulations of the global, especially the new and existing American, European and Ukrainian financial regulatory bodies and International Organizations such as IMF, FSB EU Parliament and Commission.

2. The second is to find some statistical evidence for the stabilization effect of the new regulations, especially in case of countries with a stricter supervisory framework (such as the Basel Standards) by using simple trend analysis. 
3. The third objective is to highlight the impact of the regulatory environment's changes on the existing controlling systems and tools of financial institutions. For this, the relevant financial controlling methodologies are assessed based on empirical evidence coming from the literature and logical reasoning.

\section{RESULTS - OVERVIEW OF THE KEY REGULATIONS}

Following the 2008-2009 crisis, the regulatory approach and the system have changed globally. Although some countries introduced different levels of measures, most governments and regulatory bodies have recognized the need for a global collaboration with transparent and mutually implemented standards and safety requirements. 10 years after the crisis, banks and financial markets are regulated by several laws, rules, directives and acts such as the Dodd-Frank Act, the Volcker rule, the Foreign Account Tax Compliance Act (FATCA), the Mifid II, Emir, Mifir, IFRS9, CRD/ CRR, BRRD and the Basel III accord in the European Union.

\subsection{Overview of the key global regulations}

The following key areas of actions and recommendations have been made globally:

- The formation of macro-prudential regulatory frameworks which cover: the requirement for financial institutions globally to adapt a tighter collaboration approach to the macro-prudential supervision; development of macro-prudential tools (e.g., in case of high-risk institutions G-SII, O-SII); introduction of capital maintenance buffers and systematic risk capital buffers (including the need to build counter-cyclical buffers through 'dynamic provisioning') (BCBS, 2009).

- The separation of retail and corporate banking known as 'ringfencing' to have a defined distinction between assets considered riskier compared to less risky.
- The improvement of the national and international resolution tools (through the development of the regulatory background, resolution authorities and coordinated bail-out programs).

- The attention to the liquidity and financial risks (LCR, NSFR) has increased by the regulators and the solvency requirements went through a significant restructuring (BCBS, 2010).

\section{New regulations have been introduced to target} risks related to bank size through the additional capital requirements (BCBS, 2016) and to target the relationships between the national governments and banks by promoting less governmental involvement following the crisis. Legislations also covered the introduction of the leverage ratio and the general reduction in the excessive variability of risk-weighted assets (RWA) to help restore credibility in the calculation of RWA (BCBS, 2017).

- Although the framework of stress testing has existed since the 1990's, it was mainly performed by the large international financial institutions themselves. Since the financial crisis countries around the globe introduced mandatory stress testing for large and midsize banks covering a reviewed, wider range of economic scenarios (e.g., the European Banking Authority has just launched the 2018 EU-wide stress test exercise with new methodologies). Transparency has also become a key global requirement.

In 2009 for the first time the Financial Stability Forum (later Financial Stability Board) issued a set of Principles for Sound Compensation Practices. These principles were later incorporated into the Basel III Accord and have been part of the Capital Requirement Regulation and Directive since 2013 in the European Union.

Regulators have also turned their attention to the shadow banking sector and the distributive financial technological companies (BCBS, 2017).

- In order to improve the safety of the derivatives market, official recommendations have been made to clients to transact on central counterparties (CCP). 


\subsection{Overview of the key European regulations (and the role of Basel in the stability)}

The post-crisis European regulations are generally implemented through central regulations and directives such as the Capital Requirement Directive (CRD)/Capital Requirement Regulation (CRR), Bank Recovery and Resolution Directive (BRRD), or through Regulatory Technical Standards (RTS)/ Implementing Technical Standards (ITS) and Delegated Acts. However, the backbone of the post-crisis consolidation was inevitably the Basel III accord with the coordinator role of the Basel Committee.

The role of Basel from a financial control perspective has been fundamental since the implementation of the first, Basel I accord in 1988. The rapid changes of the financial markets in the early 1990 's meant that most of its original regulations and recommendations soon become obsolete. The revised requirements of the Basel II were only first published in 1999, but due to a prolonged discussion between the regulators were only implemented in 2004. The new element of the accord was the minimal capital requirement for the financial institution, which was determined by the risk-weighted assets (RWA). Although this approach was the first to address the dynamic changes in market risks and the required mitigating measures, it still had several shortcomings as banks were only required to manage the required capital ratio and not necessarily to treat the underlying issues (e.g., issues related to risk appetite or portfolio management). For example, the rebalancing of the capital ratio could be achieved by the reduction of assets. However, in case of a systematic event many banks could try to liquidate their assets at the same time causing prices to fall and creating an even greater systemic issue. Another limitation of the RWA calculation was that the value at risk (VAR) was generally covering too short term which meant in economic expansion the required capital reserve was too little and during recession it was too much which did not enable financial institutions to move fast enough with their investments.

Considering the recent financial crisis, it is clear that the Basel II accord was primarily focusing on micro-prudential questions which in some cases amplified the pro-cyclic nature of banking operations. The systemic macro-prudential regulations were not in the forefront of the accord which meant that the financial institutions had a high degree of freedom in the process of risk and risky asset evaluation (Andersen, 2011). In order to respond to the new challenges, the Basel Committee has commissioned the establishment of the new regulatory framework known as Third Basel accord focusing on the capital adequacy of financial institutions, market liquidity risk and systematic stress testing. The Basel Committee on Banking Supervision (BCBS) originally aimed to introduce the new framework by 2013 , however due to regulatory discussions the deadline has been extended to 2018 then with a further extension until March 31, 2019.

The BCBS has recognized that leading causes of the global financial crisis were: "too much leverage with insufficient high-quality capital funding; the excessive credit growth; the high degree of systemic risk accompanied with the inadequate capital buffers; and the insufficient liquidity buffers and excessive exposure to liquidity risk" (Coen, 2016). The new framework has two balancing aims: firstly, to ensure that financial institutions are less likely to fail by setting minimum standards of resilience; secondly, to reduce the impact on the economic and financial systems in the event of failure. It could only be achieved by significantly higher requirements for loss absorption and greater emphasis on:

- higher quality and level of capital (improved definition and quality of bank capital, increased level of capital as detailed in Figure 1);

enhanced risk capture (revision of market risk framework, better capturing of securitization activities, strengthened capital requirements for counterparty cred exposure);

- leverage ratio requirement with the monitoring of excessive concentration; and macro prudential dimensions such as adequate capital buffers to mitigate various sources of systemic risk and a set of standards limiting liquidity and maturity transformation (mitigating liquidity risk) (BCBS, 2015). 


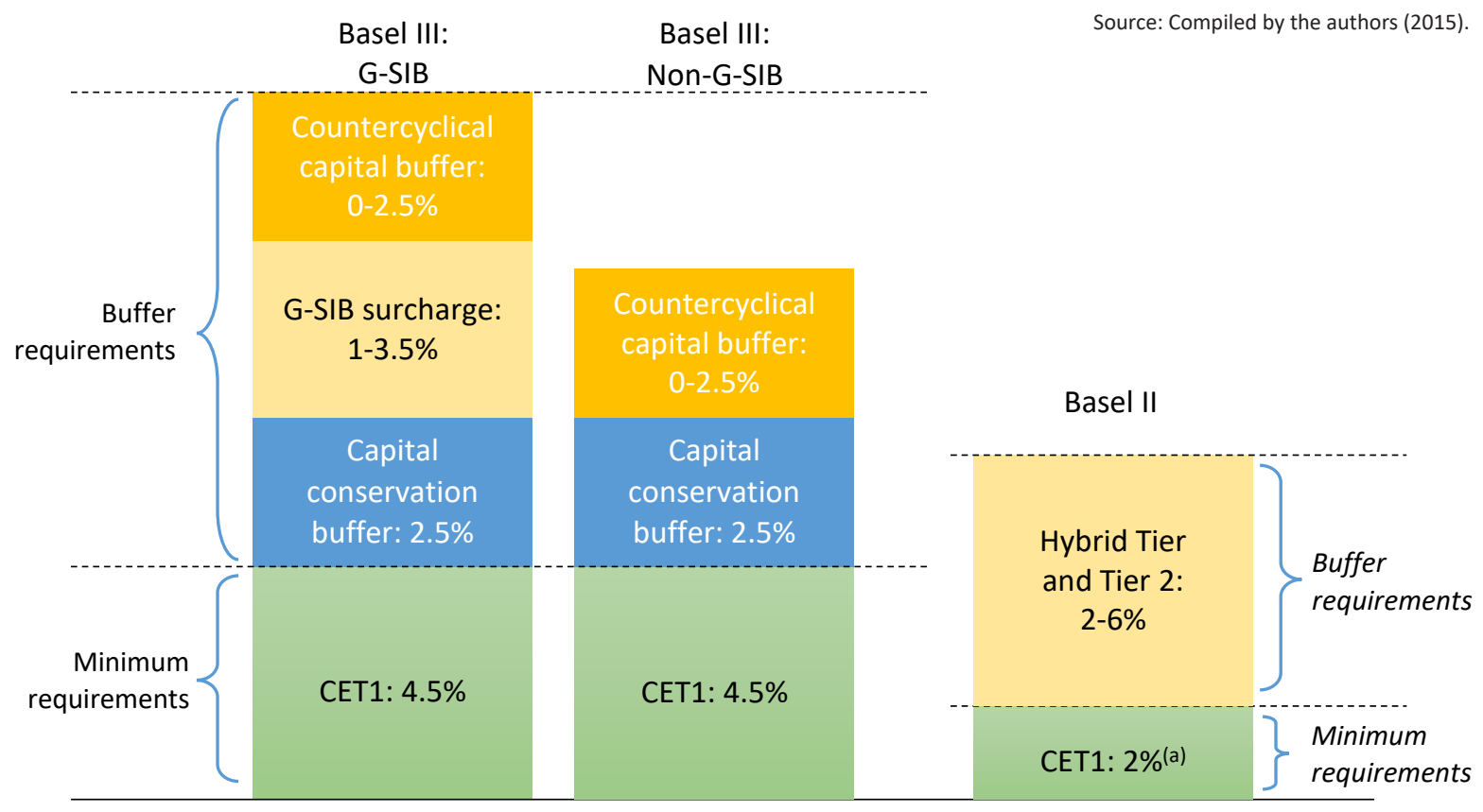

Note: (a) Assuming that the predominant part of Tier 1 capital comprised CET1.

Figure 1. Comparison of CET1 capital requirements under Basel III and Basel II

Although the Basel III framework is inevitably a key element of the post-crisis financial reforms, its true impact was interlinked with a set of complementing rules and regulations. Regulations that aimed to enhance the transparency and resilience of financial system and to address the risks, arose from outside of the regulated banking system. On top of the regulations mentioned in the global overview section the following additional key European regulations and directives have been introduced in the past decade:

- The stability of the Financial Instruments Market was a key focus of the European regulations. The existing regulations were enhanced with the introduction of the revised Markets in Financial Instruments Directive (Mifid II) which sets out: the conduct of business and organizational requirements for investment firms; authorization requirements for regulated markets; regulatory reporting to avoid market abuse; trade transparency obligation for shares; and rules on the admission of financial instruments to trading. Researches already suggest an imminent positive change in forecasting practices of the affiliated analysts' long-term earnings predicting behavior (Prokop \& Kammann, 2018).
- On top of the prudential and conduct regulations the policymakers have also reviewed and developed new regulations driven by the rapid technology changes. For example, since January 2018, the Payments Services Directive 2 (PSD2) will require banks to share their customer information with third parties; such as payments of firms in a regulated manner. This and other regulations such as the General Data Protection Regulation (GDPR) have a major impact on the primarily data driven financial industry.

\subsection{Overview of the key Ukrainian regulations}

Many countries outside of the European Union voluntarily follow the Basel standards and implemented several elements of the CRDs and CRRs through the adaption of different RTSs and ITSs. However, the history of the Ukrainian post-crisis banking regulations differs from the European or American regulation history. Mainly since the Ukrainian banking sector has suffered another systemic banking crisis between 2014-2017 shortly after the 2008-2009 global crisis (Ramskyi et al., 2017). Although the Ukrainian bank supervision practices and regulations were influenced by the 
global trends, the approaches to risk management were not harmonized with international standards like the Basel Accord.

Following the 2008-2009 financial crisis, Ukraine was granted over 16 billion USD loan in 2008 followed by 15 billion USD in 2010, 17 billion in 2014 (one of the largest loans since Ukraine became a member of the IMF and the World Bank in 1992), another 17 billion in 2015 and 1 billion USD in 2017 by the International Monetary Fund (IMF) (International Monetary Fund, 2014). While these loans catalyzed the economic recovery processes and the reform initiatives, this also meant that Ukraine had to comply with several conditions set out by the Memorandum of Economic and Financial Policies (the "MEFP") which became the first key legislative framework post the 2008-2009 financial crunch (Zavadetskyi, 2018).

During the second banking crisis several, amendments and further legislations have been introduced (e.g., laws to simplify procedures to reorganize and recapitalize banks; or amendments to the Codes of procedure affecting banks' activity; the new laws on Consumer lending; and the laws on Financial Restructuring, etc.). Probably the most significant progression was made by the National Bank of Ukraine (NBU) and the Ukrainian government on changing the existing supervision practices from the "rule-based" approach to a "risk-based" process (Zavadetskyi, 2018) by working towards the full compliance with the Basel Core Principles and EU directives (further discussed in the Result section) with the ultimate goal to fully introduce the Basel III standards by 2019 .

\section{IMPACT OF REGULATION CHANGE ON THE BANKING SYSTEM}

The post-crisis regulatory actions had two purposes: first, to stabilize the financial markets through tactical solutions; second, to develop long-term controls and regulations that prevent a similar future crisis. Although there has been a cross border collaboration across several countries, different regions around the globe had different level of reg- ulatory response to the financial crisis. Economic evidence can found for the effectiveness of the chosen complexity of regulations by analyzing the macroeconomic and financial data of the IMF. Out of the over 40 metrics in the Financial Soundness Indicator set, the percentage of Non-performing Loans to the Total Gross Loans trend (Figure 2) and the percentage of Regulatory Tier 1 Capital to RWA (Figure 3) helps to highlight the impact of the different consolidation efforts.

For both analyses, four groups have been assessed. The EU28 countries represent a combination of Basel III regulations with additional rules set out by the European Parliament. The Basel Committee Members represent a primarily Basel III regulation led group. These groups are compared against the Hungary and Ukraine. Although the financial systems of both countries face similar shock due to the rapid change in the currency, Hungary as an EU member had to comply with the EU and Basel regulations early compared to Ukraine which voluntarily started the adoption of the Basel principles following the second banking crisis, therefore these groups can reflect the difference in the regulatory approach.

The percentage of Non-performing Loans to the Total Gross Loans trend (Figure 2) is intended to identify problems with asset quality in the loan portfolio. The graph shows the same trend and levels of the ratio between 2010 and 2012 for Ukraine and Hungary (the trend is similar for the EU28 average, however, the levels stay below 10\%). Following the corrective actions and the regulations, both the EU28 average and the trend of the Hungarian ratio are showing significant improvements (the ratio went down from $17 \%$ in 2013 to 4\% in 2017 in Hungary). At the same time, the ratio has significantly worsened in Ukraine (the ratio increased from 13\% to 55\% between 2013 and 2017) due to multiple factors one being the late regulatory intervention.

The percentage of regulatory tier 1 capital to RWA ratio is a complex measure of change in risk and countermeasures at the same time. The ratio shows a constant improvement across the EU28 and Basel countries indicating the improved methodology of RWA calculation and the increased minimum capital levels. At the same time, the different 


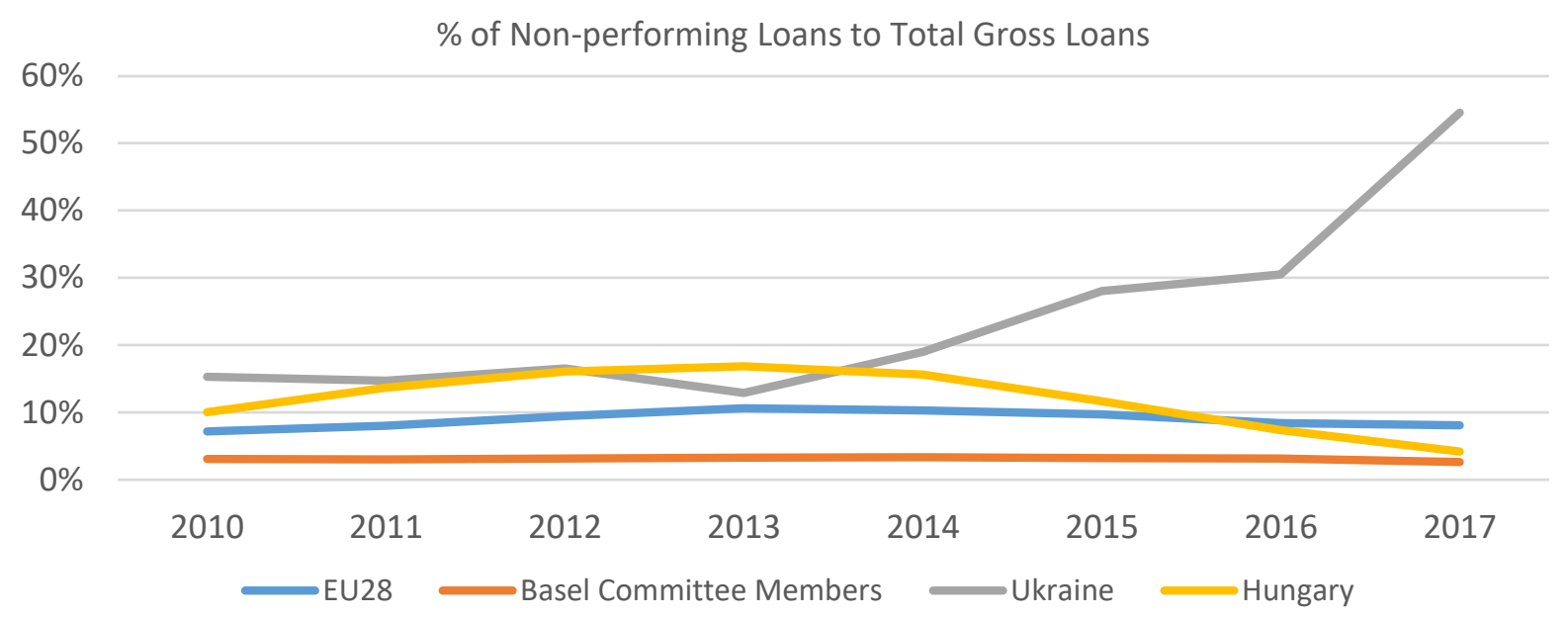

Figure 2. Impact of post-crisis regulations on bank stability (trend of non-performing loans)

regulatory environment resulted in a significant jump in the RWA stock in Ukraine. The corrective actions taken based on the IMF requirements have increased the capital level, however it is still 6 percent points less compared to the EU28 average. This with the percentage of Non-performing Loans to the Total Gross Loans provides some empirical evidence to the stabilizing effect of the post-crisis regulations.

\section{BANK GOVERNANCE AND CONTROLLING TOOLS}

Following the financial crisis, the importance of internal governance and control of financial institutions has appreciated. The focus has shifted from the pure profit- and product-oriented internal control towards an effective, sustainable and profitable management control, where besides the basic services the organizations are aiming to add value for the investors, the customer and the internal stakeholders. In order to achieve this, banks have developed a new complex planning and controlling system that is adapted to the new challenges and focusing on financials, customers, internal culture, compensations and market at the same time rather than primarily on governance of financials or administrative controls only (Kalmar et al., 2014).

As recent studies (CIMA, 2016; Lintner \& Lincoln, 2016) found, the roles and importance of management control professionals and control systems have changed in parallel with the appearance of

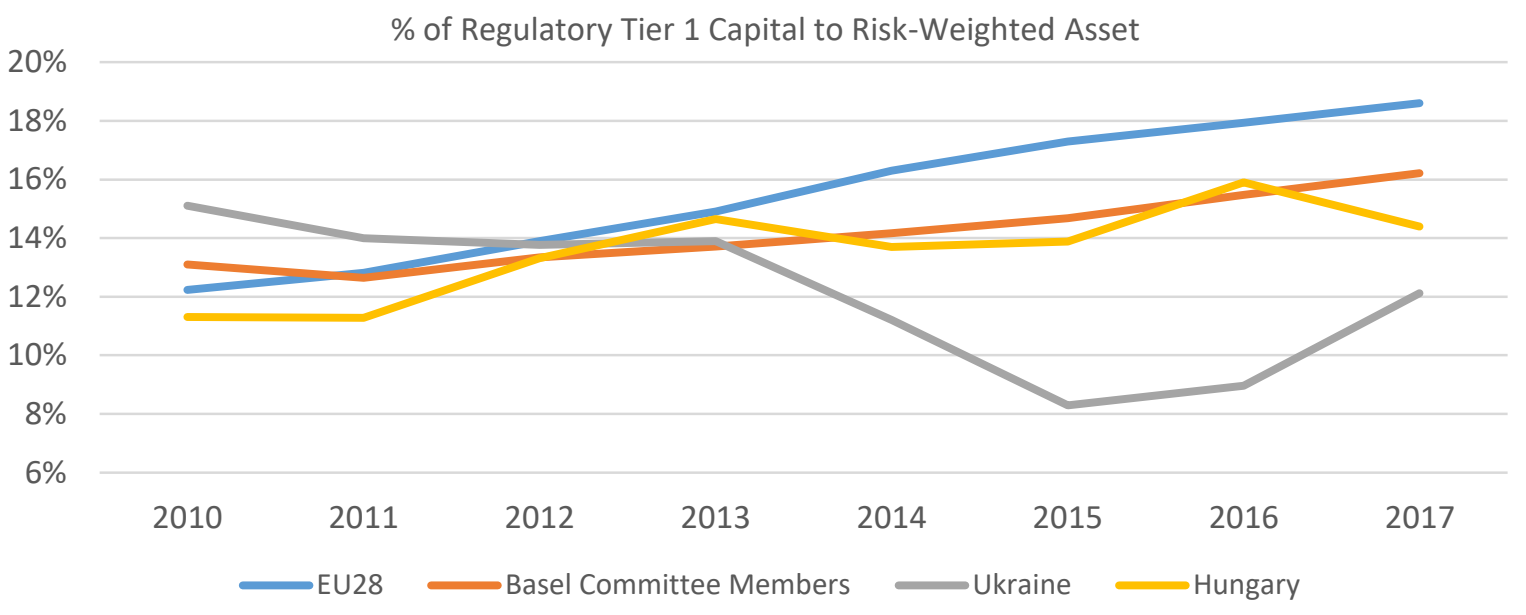

Figure 3. Impact of post-crisis regulations on bank stability (trend of capital to RWA) 
Table 1. Comparison of pre- and post-crisis bank control functionalities

Source: Own summary based on CIMA (2016) and Lintner \& Lincoln (2016).

\begin{tabular}{|c|c|c|}
\hline Functions & Pre-crisis & Post-crisis \\
\hline Planning & $\begin{array}{l}\text { General planning processes, main focus was } \\
\text { on short to medium-term planning }\end{array}$ & $\begin{array}{l}\text { No significant changes to planning processes. Importance of } \\
\text { long-term planning and capital management planning has } \\
\text { increased }\end{array}$ \\
\hline Financial control & $\begin{array}{l}\text { Budget planning used to be linked to } \\
\text { 12-month period, using traditional budgeting } \\
\text { methods with a financial KPI measure set }\end{array}$ & $\begin{array}{l}\text { New budgeting methodologies (Beyond Budgeting) had } \\
\text { been adapted, } 1-3 \text { years budgeting practice, increased focus } \\
\text { on ROE, liquidity, capital ratios and cost/profit measures }\end{array}$ \\
\hline $\begin{array}{l}\text { Administrative } \\
\text { control }\end{array}$ & $\begin{array}{l}\text { Main focus on governance and organization } \\
\text { structure, policies and procedures }\end{array}$ & $\begin{array}{l}\text { Administrative control extents to comprehensive risk } \\
\text { controls, governance and compliance management as well } \\
\text { as improved internal audit processes }\end{array}$ \\
\hline Cultural control & $\begin{array}{l}\text { Main extension of this function is the } \\
\text { identification of fundamental values on which } \\
\text { banks operate }\end{array}$ & $\begin{array}{l}\text { Function extends to support embedding of values in the } \\
\text { organization through hiring practices, social events and } \\
\text { mentoring programs for managers and employees }\end{array}$ \\
\hline $\begin{array}{l}\text { Reward and } \\
\text { compensations }\end{array}$ & Mainly planning and monitoring function & $\begin{array}{l}\text { Plays key role in the design and control of reward and } \\
\text { compensation schemes, especially following the regulations } \\
\text { on manager remuneration }\end{array}$ \\
\hline $\begin{array}{l}\text { Information } \\
\text { management }\end{array}$ & $\begin{array}{l}\text { Main focus on internal reporting with } \\
\text { information collecting functions }\end{array}$ & $\begin{array}{l}\text { Focus on internal and external reporting with central } \\
\text { information distribution functions }\end{array}$ \\
\hline
\end{tabular}

new regulations, standards, requirements and legislations. To understand the direction of these changes, using the case studies and findings of the previously mentioned researches has been created. It highlights some key changes in the con- trol functionalities based on empirical data. The aspects used for the comparison are based on the Malmi and Brown management controls as a package model (Malmi \& Brown, 2008). The following observations can be made in Table 1 .

\section{CONCLUSION}

The excessive and uncontrolled credit growth, the high levels of leverage with insufficient high-quality capital funding, the high degree of systemic risk accompanied with the inadequate capital buffers and the insufficient liquidity buffers and excessive exposure to liquidity risk (Coen, 2016) in the early 2000's led to first global financial crisis of the millennium in 2008-2009. It soon became clear for governments and central banks around the globe that the existing "free banking" regulatory approach and the system had to change. Many countries recognized the challenges of global markets and the fact that the impact of their national policies was likely to go across borders, which required governments to coordinate not just regionally but also globally.

New regulatory bodies and various regulations, such as the Dodd-Frank Act, the Volcker rule, the Foreign Account Tax Compliance Act (FATCA), the Mifid II, Emir, Mifir, IFRS9, CRD/CRR, BRRD, GDPR and the Basel III accord, have been introduced in the past decade. As a result, adequate controls have been set up globally covering the following areas:

- $\quad$ structural changes to system of regulatory bodies and supervision (Dodd-Frank Act);

- regulation of investment, insurance and derivatives market (Dodd-Frank Act, Mifid II);

- enhanced risk capture and capital requirements (Basel III);

- leverage ratio requirement with the monitoring of excessive concentration (Basel III);

- macro prudential dimensions control to mitigate liquidity and financial risks (Basel III);

- separation of retail and corporate assets (PRA in the UK); 
- improvement of the national and international resolution tools (EC);

- comprehensive stress testing for risk prevention (EBA);

- improved tax regulation and transparency (FATCA).

Although there has been a global effort to consolidate the financial markets, different countries had different levels of regulatory response to the financial crisis. By analyzing the macroeconomic and financial data, indication for the impact of the chosen regulatory approach was found. The analysis has highlighted that in countries (EU28, Basel Committee Members) where complex regulations were introduced soon after the crisis, buffer levels and non-performing loan ratios have significantly improved within the assessed seven years compared to countries, such as Ukraine, with a late intervention.

Finally, one can see that the changes in the regulatory environment have increased the roles and importance of management control professionals and internal control systems. As the assessed case studies suggested new budgeting methodologies (Beyond Budgeting) had been adapted, the administrative control function now included comprehensive risk controls, governance and compliance management as well as improved internal audit processes. Reward and Compensations control has become a key part of the controlling systems and information coordinating function has expanded to multiple areas of the bank operations.

\section{ACKNOWLEDGMENT}

In part of Prof. Lentner this study was supported by PADA (Hungarian National Bank Foundation) Leader Expert Program.

\section{REFERENCES}

1. Andersen, H. (2011). Procyclical implications of Basel II: Can the cyclicality of capital requirements be contained? Journal of Financial Stability, 7(3), 138-154. https://doi org/10.1016/j.jfs.2010.05.001

2. BCBS (2009). Strengthening the resilience of the banking sector. Basel: Bank for International Settlements. Retrieved from https://www.bis.org/publ/bcbs164. htm

3. BCBS (2010). An assessment of the long-term economic impact of stronger capital and liquidity requirements. Basel: Bank for International Settlements. Retrieved from https://www.bis. org/publ/bcbs173.pdf

4. BCBS (2015). Finalising postcrisis reforms: an update (A report to G20 Leaders). Basel: Bank for International Settlements. Retrieved from https://www.bis. org/bcbs/publ/d344.pdf
5. BCBS (2016). Minimum capital requirements for market risk. Basel: Bank for International Settlements. Retrieved from https://www.bis. org/bcbs/publ/d352.pdf

6. BCBS (2017, December). Basel III: Finalising post-crisis reforms. Basel: Bank for International Settlements. Retrieved from https://www.bis. org/bcbs/publ/d424.pdf

7. BCBS (2017, August). Implications of fintech developments for banks and bank supervisors. Basel: Bank for International Sttlements. Retrieved from https://www.bis. org/bcbs/publ/d415.pdf

8. BIS (2010). Interim report: Assessing the macroeconomic impact of the transition to stronger capital and liquidity requirements. Macroeconomic Assessment Group established by the Financial Stability Board and the Basel Committee on Banking Supervision.
9. CIMA (2016). Financial crisis and changes in managment controls in banks. London: Chartered Institute of Management Accountants. Retrieved from https://www.cimaglobal.com/ Documents/Governance\%20 documents/4281\%20Financial\%20 crisis\%20and\%20changes\%20academic\%20research\%20report\%20 FINAL.PDF

10. Coen, W. (2016). Finalising Basel III - Introductory remarks. European Parliament's Committee Meeting on Economic and Monetary Affairs (ECON Committee). Brussels. Retrieved from https://www.bis.org/speeches/sp161012.htm

11. Dodd, C., \& Frank, B. (2010). Dodd-Frank Wall Street Reform and Consumer Protection Act. Retrieved from https://www. congress.gov/111/plaws/publ203/ PLAW-111publ203.pdf 
12. European Commission (2010, September 15). Summary of the impact Assessment, Accompanying document to the proposal for a REGULATION OF THE EUROPEAN PARLIAMENT AND OF THE COUNCIL on OTC derivatives, central counterparties and trade repositories. Retrieved from http://ec.europa.eu/internal_ market/financial-markets/docs/ derivatives/20100915_impact_assessment_en.pdf

13. European Parilament (2010, June 28). European Parliament resolution of 8 October 2009 on the Pittsburgh G-20 Summit of 24 and 25 September 2009. Retrieved from http://www.europarl.europa.eu/ sides/getDoc.do?pubRef=-//EP// NONSGML+MOTION+P7-RC2009-0082+0+DOC+PDF+V0//EN

14. Financial Stability Oversight Council (2011). Annual Report. U.S. Department of the Treasury. Retrieved from https://www.treasury.gov/initiatives/fsoc/Documents/FSOCAR2011.pdf

15. Handorf, W. C. (2017). Financial implications of transitioning to the Wall Street Reform and Consumer Protection Act of 2010 and Basel III. Journal of Banking Regulation, 18(1), 1-13. https://doi. org/10.1057/jbr.2015.5

16. Hanggraeni, D. (2018). Competition, bank fragility, and financial crisis. Banks and Bank Systems, 13(1), 22-36. http://dx.doi. org/10.21511/bbs.13(1).2018.03
17. Hartwell, C. (2012). The role of central banks in maintaining monetary stability during the global financial crisis. Banks and Bank Systems, 7(3), 51-67. Retrieved from https://businessperspectives.org/images/pdf/ applications/publishing/templates/article/assets/4867/BBS_ en_2012_3_Hartwell.pdf

18. International Monetary Fund (2014, April). Ukraine: Assessment of the Risks to the Fund and the Fund's Liquidity Position. Washington, DC: IMF. Retrieved from http://www.imf.org/external/ pubs/ft/scr/2014/cr14106.pdf

19. Kalmar, P., Lukacs, J., Barczi, J., Hajos, L., \& Zeman, Z. (2014). Bank services and product marketing controlling: Applying multivariate method for customer satisfaction variance analysis. Annals of Faculty of Engineering Hunedoara - International Journal of Engineering, 12(3), 229-234.

20. Kapoor, S. (2010). The financial crisis - causes and cures. Brussels: Bertelsmann Stiftung, Friedrich Ebert Stiftung.

21. Lintner, P., \& Lincoln, J. (2016) Bank resolution and "Bail-in" in the EU: selected case studies pre and post BRRD. Vienna: World Bank Group (Financial Sector Advisory Center).

22. Malmi, T., \& Brown, D. A. (2008). Management control systems as a package - opportunities, challenges and research directions. Management Accounting Research, 19(4), 287-300.

23. Moosa, I. A., Ramiah, V., \& $\mathrm{Xu}, \mathrm{X}$. (2015). Neoclassical finance, behavioral finance and noise traders: A review and assessment of the literature. International Review of Financial Analysis, 41(C), 89-100. Retrieved from http://www.sciencedirect.com/science/article/pii/ S1057521915001039

24. Prokop, J., \& Kammann, B. (2018). The effect of the European Markets in Financial Instruments Directive on affiliated analysts' earnings forecast optimism. Journal of Economics and Business, 95, 75-86. https://doi.org/10.1016/j. jeconbus.2017.06.004.

25. Ramskyi, A., Loiko, V., SobolievaTereshchenko, O., Loiko, D., \& Zharnikova, V. (2017). Integration of Ukraine into the Eurpoean Banking System: Cleaning, Rebooting and Basel III. Banks and Bank Systems, 12(4), 163 174. http://dx.doi.org/10.21511/ bbs.12(4-1).2017.05

26. Rothbard, M. N. (2008). The Mystery of Banking ( $2^{\text {nd }}$ ed.) (pp. 110-125). Auburn (Alabama): Ludwig von Mises Institute.

27. Zavadetskyi, O. (2018). Ukraine. In P. Hsu, \& R. Bahar (Eds.). Banking Regulation 2018 (Fifth Edition) (p. 352). London: Global Legal Insights. 